\title{
New flavonoid with antidiabetic and antioxidant potential from Tetrastigma angustifolia (Roxb.) Deb leaves
}

\author{
Julfikar Ali Junejo ${ }^{1^{*}}$, Kamaruz Zaman ${ }^{1}$, Mohammed Ali², Mithun Rudrapal ${ }^{\oplus 1}$ \\ ${ }^{1}$ Department of Pharmaceutical Sciences, Dibrugarh University, Dibrugarh, \\ Assam, India, ${ }^{2}$ Department of Pharmacognosy and Phytochemistry, Faculty \\ of Pharmacy, Jamia Hamdard, Hamdard Nagar, New Delhi, India
}

\begin{abstract}
Ethnomedicinal survey documents the traditional practices of Tetrastigma angustifolia leaves in the management of diabetes in the North-eastern region of India. The present study was aimed at isolation of possible antidiabetic principle(s) from $T$. angustifolia leaves and evaluation of antidiabetic efficacy of isolated compound(s) in experimental animal model. The methanolic extract of T. angustifolia leaves was obtained by Soxhlet extraction method and subjected to silica gel column chromatography (100200 mesh). Fraction 18-176 chloroform:methanol (70:30) yielded a pale yellow colored compound. The structure of pure compound was elucidated with the help of UV, IR, NMR and Mass spectrometric/ techniques. The antioxidant activity of the isolated compound was evaluated in vitro by various radical scavenfing assay methods.. Oral acute toxicity study was carried out according to OECD guideline 423 in Wistar rats. The antidiabetic efficacy of the isolated compound was evaluated in STZ-induced diabetic rats at the dose of $5 \mathrm{mg} / \mathrm{kg}$ b.w. for duration of 21 days. The present study reports a new flavocnoid compound isolated from the methanolic extract of T. angustifolia leaves and identified as 8-hydroxyapigenin 7-O-Dglucopyranoside. The flavonoid compound exhibited potent antidiabetic (hypoglicemic) activity in STZinduced diabetic rats with promising antioxidant (radical scavenging activity) potential in vitro.
\end{abstract}

Keywords: T. angustifolia. Leaves. Flavonoid. Antidiabetic. Antioxidant. Lead molecule.

\section{INTRODUCTION}

Diabetes mellitus (or Diabetes) is a metabolic disorder characterized by hyperglycemia with abnormal carbohydrate, fat and protein metabolism resulting from defects in insulin secretion, insulin action or both(Amira et al., 2016).Hyperglycemia is usually accompanied by polyuria, polydipsia, weight loss, sometimes polyphagia,blurred visionand alsosusceptibility to infectious illness.In diabetes, chronic hyperglycemic condition may leadto several healthcomplicationssuch as cardiovascular (cardiomyopathy),neurological (neuropathy), renal (nephropathy) and ocular

*Correspondence: K. Zaman. Department of Pharmaceutical Sciences Dibrugarh University Dibrugarh-786004, Assam, India. Tel.: +91 373 2370254.E-mail: kzaman71@dibru.ac.in (retinopathy)complications (Shokeenet al., 2008). The prevalence of diabetes is increasing with the global rise of obesityand relatedlife style disorderslike heart diseases and hyperlipidaemia.According to the latest report of World Health Organization (WHO, 2016), approximately 420 million adults are living with diabetes mellitus. Type 2 diabetes mellitus (Non-insulin Dependent Diabetes Mellitus) is alone responsible for up to $90 \%$ of total diabetes prevalence,which is the fourth leading cause of death worldwide(Irudayarajet al., 2012; Kumar, Kumar, Om, 2011).

Oxidative stress (OS) is believed to be theunderlyingcause of cellular injury, tissue damage or organ dysfunctions commonlyassociated with diabetic complications. OS refers to elevated intracellular levels of reactive oxygen species (ROS) that cause damage to bio-molecules like lipids, proteins and DNA(Mahdi et 
al., 2003). Cellular OS may be reduced to a considerable extent by the defense mechanism of variousantioxidant enzymes such as superoxide dismutase (SOD), catalase (CAT), glutathione reductase (GSH) and glutathione peroxidase(GPx)available in our body (Souza, Rao, Silveira, 1997). Besides antidiabetic drugs, antioxidant medications arre also used as adjuvant therapy in alleviating the long term complications of diabetes mellitus. Despite the availability of synthetic hypoglycemic agents, diabetes is still life-threatening because of their limited therapeutic utility.Moreover, these drugs produce some potential side effects, such as drug resistance, dropsy and weight gain. In contrary, herbal traditional medicines play a significant role in the management of diabetes mellitus (Patel, Srivivasan, 1997). WHO recommended the evaluation of such herbal remedies used in the treatment of diabetes,since they are effective and safe compared to synthetic drugs (Day, 1998).Many indigenous Indian medicinal plant based drugs or herbal preparations are being usedin the treatment of diabetes mellitus (Sabu, Smitha, Kuttan, 2002).

Tetrastigma angustifolia (Roxb.) Deb (Family: Vitaceae) is an evergreen shrub distributed widely in India, Sri Lanka, Southern China, Thailand and other parts of Southeast Asia. In North-eastern region of India, it is locally known as Naltanga. The whole plant is used as green vegetable by different ethnic communities in North-eastern region ofIndia.T. angustifolia is used for thousand years in Indian Systems of Medicine like Ayurveda and is also a useful traditional home remedy against diabetes. T. angustifolia has diversified biological activities such as antidiabetic, anti-inflammatory, antioxidant, antidiarrhoeal, antibacterial, antifungal and hypolipidemic. Ethnomedicinal survey documented the use of leaves of $T$. angustifolia in the management of diabetes by several ethnic communities in Assam state of India. Earlier we reported the antidiaetic property of hydroalcoholic extract of $T$. angustifolia leavesand also the presence of phenolic and flavonoid contents in thehydroalcoholic extract of leaves of the plant. Literature suggests that leaves of T. angustifolia are rich in flavonoids (Junejo et al., 2014).Plant flavonoids have a wide range of pharmacological responses which include anticancer, anti-HIV, antioxidant, antidiabetic and antiinflammatory properties. Literature also demonstrates plant flavonoids have dramatic role in glucose lowering and antioxidant properties (Irudayaraj et al., 2012; Debasis et al., 2010).
In view of above facts, the present study was aimed atisolation of antidiabetic principle(s) from the $T$. angustifolia leaves, along with evaluation of antidiabetic potential of isolated compounds(s) in STZ-induced diabetic rats. Accordingly, a new flavonoid was isolated from the methanolic leaf extract of $T$. angustifolia, andthe toxicological, antidiabeteticand antioxidant properties of the isolated flavonoid were studies using standard in vitro and in vivo experimental models. Since a biochemical relationship exists between hyperglycemia and cellular oxidative stress in diabetes, the evaluation of antioxidant property was also carried out along with the antidiabetic activity to assess the antidiabetic potential of isolated flavonoid as novel herbal antioxidant.

\section{MATERIAL AND METHODS}

\section{Chemicals and analysis}

All chemicals, solvents and reagents used in the study were of analytical grade and were procured from Rankem, Mumbai and Himedia Laboratories Ltd., Mumbai.Streptozotocin(STZ) was procured from SigmaAldrich, Germany. Commercial reagent kits used for determination of biochemical parameters and enzymatic assays were purchased from SPAN Diagnostics Ltd., Surat (India).Melting points (MP) were measured in open capillaries on an electrically heated melting point apparatus. Thin layer chromatography (TLC) $(0.5 \mathrm{~mm}$ thick layer) was carried out on silica gel $G$ plates with fluorescent indicator (Merck, Germany) and spots were visualized by iodine vapors. Ultraviolet (UV)-visible spectra were recorded on Shimadzu UV-1700 UVvisible spectrophotometer.Infrared (IR) spectra were obtained on a Bruker AlphaFourier Transform (FT-IR) spectrometer using KBR disc. ${ }^{1} \mathrm{H} \&{ }^{13} \mathrm{C}$ Nuclear Magnetic Resonance (NMR) spectra were recorded on Bruker Avance II 400 FT-NMR spectrometer at 400 and 100 $\mathrm{MHz}$, respectively using tetramethylsilane (TMS) as an internal standard $(\delta 0.00 \mathrm{ppm})$ and deuterated dimethyl sulfoxide $\left(\mathrm{DMSO}-\mathrm{d}_{6}\right.$ ) as a solvent. Mass spectra were obtained on a LC-MS Water 4000 ZQ instrument using electrospray ionization $\left(\mathrm{ES}^{+}\right)$.

\section{Plant material}

Fresh leaves of Tetrastigma angustifolia (Roxb.) Deb was collectedfrom forest areas of Dibrugarh district, Assam (India) during the month of December 
2014. The plant species was identified and authenticated by Dr A. A. Mao, Scientist E, Botanical Survey of India, Eastern Regional Centre, Shillong (India). A voucher specimen(BSI/ERC/Tech./Plant Iden./2014/830) of the identified plant species was deposited in the Herbarium of the Department of Pharmaceutical Sciences, Dibrugarh University, Dibrugarh.

\section{Extraction and isolation of the active compound}

The plant material (1.5 $\mathrm{kg}$ leaves) was air-dried under shade, coarsely powdered (Sieve no. 40) and defatted with petroleum ether $\left(60-80^{\circ} \mathrm{C}\right)$ using Soxhlet apparatus by successive solvent extraction method (Chakraborty, Saha, Mukhapadhyay, 2009).Later, extraction was performed using methanol using Soxhlet apparatus and the extracted sample was evaporated to dryness using rotary vacuum evaporator. The final yield of the extract was $24.32 \%$, calculated per dry weight of powdered leaves.The dried methanolic extract (200 g) obtained as black brown residue was then subjected to column chromatography (silica gel packed column, 100-200 mesh, $250 \mathrm{~g}$ ) by pre-adsorbing with silica gel $(150 \mathrm{~g})$. The extract was eluted first using chloroform $(100 \%)$, followed by the mixture of chloroform and methanol at various ratios $(90: 10,70: 30,50: 50$, $30: 70 \& 10: 90)$ andthen finally by methanol (100\%). Fractions $(200 \mathrm{~mL}$ each) obtained from the column were collected and combined on monitoring TLC. Thin layer Chromatography studies were performed using readymade pre-coated silica gel plates (Merck) with fluorescent indicator. Two hundred fractions were obtained. Fraction 18-176, chloroform:methanol (70:30) yielded a pale yellow colored compound. The crude compound was recrystallized from methanol. The compound was identified as flavonoid (TAY) with the chemical name of 8-hydroxy-apigenin-7-O- $\beta-D-$ glucopyranoside.

The presence of flavonoids in the extract was determined using Pews' test (Anwal et al., 2014). $1.0 \mathrm{~mL}$ of aqueous extract $(5 \% \mathrm{w} / \mathrm{v})$ was mixed with $0.02 \mathrm{~g}$ of metallic zinc and $1.5 \mathrm{~mL}$ conc. sulphuric acid. The formation of red color indicated the presence of flavonoids.

\section{Test animals}

Healthy Wistar male albino rats (240-260 g) were maintained under standard environmental conditions (temperature $25 \pm 2{ }^{\circ} \mathrm{C}$, relative humidity $50 \pm 5 \%$ ) with a $12 \mathrm{~h} \mathrm{light/dark} \mathrm{cycle.} \mathrm{They} \mathrm{were} \mathrm{fed} \mathrm{on} \mathrm{with} \mathrm{normal}$ laboratory chow pellet diet and drinking water was given ad libitum. Animals were allowed to acclimatizefor 7 days before commencement of the experiment. The animals were used with the approval of the Institutional Animal Ethics Committee (Approval no. IAEC/DU/50 dt. 24.9.13)under guidelines set by the Committee for the Purpose of Control and Supervision of Experiments on Animals (CPCSEA), New Delhi (India).

\section{In vitro antioxidant activity}

The in vitro antioxidant activity of the isolated flavonoid, TAY was carried out using the following three assay methods in accordance with previously reported procedures with minor modifications.

\section{Superoxide radical scavenging activity}

Superoxide radical scavenging activity was determined by the nitro blue tetrazolium (NBT) reduction method(McCord, Fridovich, 1969). In this assay, the non-enzymatic phenazinemethosulfate/nicotinamide adenine dinucleotide (PMS/NADH) system generates superoxide radicals, which reduce NBT to a purple color formazan. The reaction mixture contained phosphate buffer $(0.5 \mathrm{~mL}, 100 \mathrm{mM}, \mathrm{pH} 7.4), 1.0 \mathrm{~mL}$ of NADH $(0.4 \mathrm{mM}), 1.0 \mathrm{~mL}$ of NBT $(0.156 \mathrm{mM}), 0.1 \mathrm{~mL}$ of PMS $(0.06 \mathrm{mM})$ and $3 \mathrm{~mL}$ of the TAY/standard drugs (quercetin \& gallic acid) of various concentrations (10$50 \mu \mathrm{g} / \mathrm{mL}$, in $90 \%$ ethanol). After incubation at $25{ }^{\circ} \mathrm{C}$ for $1 \mathrm{~h}$, the absorbance of the reaction mixture was measured at $560 \mathrm{~nm}$ against an appropriate blank to determine the quantity of formazan formed.

\section{Hydroxyl radical scavenging activity}

Hydroxyl radicals were generated by the Fenton reaction using $\mathrm{Fe}^{3+} /$ ascorbate/EDTA/ $\mathrm{H}_{2} \mathrm{O}_{2}$ system. The hydroxyl radical generated in the system attacks deoxyribose which eventually results in the formation of thiobarbituric acid (TBA, which reacting substance (TBARS) which was estimated (Elizabeth, Rao, 1990). The reaction mixture contained $0.1 \mathrm{~mL}$ of 2-deoxy-2ribose $(10 \mathrm{mM}), 0.33 \mathrm{~mL}$ of phosphate buffer $(50 \mathrm{mM}, \mathrm{pH}$ 7.4), $0.1 \mathrm{~mL}$ of $\mathrm{FeCl}_{3}(0.1 \mathrm{mM}), 0.1$ mlethylenediamine tetra-acetic acid (EDTA) $(0.1 \mathrm{mM}), 0.1 \mathrm{~mL}$ of $\mathrm{H}_{2} \mathrm{O}_{2}$ $(2 \mathrm{mM}), 0.1 \mathrm{~mL}$ of ascorbic acid $(1 \mathrm{mM})$ and $1.0 \mathrm{~mL}$ 
of various concentrations $(5-50 \mu \mathrm{g} / \mathrm{mL})$ of the $T A Y /$ standards (quercetin \& gallic acid).After incubation for $45 \mathrm{~min}$ at $37^{\circ} \mathrm{C}, 1.0 \mathrm{~mL}$ of $2.8 \%(\mathrm{v} / \mathrm{v}) \mathrm{TCA}$, and $1.0 \mathrm{~mL}$ of [thiobarbituric acid, TBA, $0.5 \%(\mathrm{v} / \mathrm{v})$ in $0.025 \mathrm{~mol} / \mathrm{L}$ $\mathrm{NaOH}$ solution containing $0.2 \%(\mathrm{w} / \mathrm{v})$ of butylated hydroxyl anisole, BHA] were added in the reaction mixture, and the mixture was incubated at $95{ }^{\circ} \mathrm{C}$ for 15 min to develop the pink chromogen. After cooling, the absorbance was measured at $532 \mathrm{~nm}$ against an appropriate blank solution.

\section{Lipid peroxidation scavenging activity}

The $\mathrm{Fe}^{3+} /$ ascorbic acid dependent non-enzymatic lipid peroxidation in the liver extract was performed as follows. Reaction mixture $(0.5 \mathrm{~mL})$ containing rat liver homogenate $(0.1 \mathrm{~mL}, 25 \% \mathrm{w} / \mathrm{v})$ in Tris- $\mathrm{HCl}$ buffer (40 mM, pH 7.0), $\mathrm{KCl}(30 \mathrm{mM}), \mathrm{FeCl}_{3}(0.16 \mathrm{mM})$ and ascorbic acid $(0.06 \mathrm{mM})$ was incubated for $1 \mathrm{~h}$ at $37^{\circ} \mathrm{C}$ in the presence and absence of the TAY/standard drugs (quercetin \&gallic acid)at various concentrations (50$250 \mu \mathrm{g} / \mathrm{mL}$ ). The lipid peroxide formed was measured by TBARS formation (Ohkawa, Ohishi, Yagi, 1979). For this incubation mixture $0.4 \mathrm{~mL}$ was treated with sodium dodecyl sulphate $(8.1 \%, 0.2 \mathrm{~mL})$, TBA $(0.8 \%$, $1.5 \mathrm{~mL})$ and acetic acid $(20 \%, 1.5 \mathrm{~mL}, \mathrm{pH} 3.5)$. The total volume was then made upto $4.0 \mathrm{~mL}$ by adding distilled water and kept in a water bath at $100{ }^{\circ} \mathrm{C}$ for $1 \mathrm{~h}$. After cooling, $1 \mathrm{~mL}$ of distilled water and $5.0 \mathrm{~mL}$ of a mixture of $n$-butanol and pyridine $(10: 1 \mathrm{v} / \mathrm{v})$ were added to the reaction mixture, shaken vigorously and centrifuged at $4000 \mathrm{rpm}$ for $10 \mathrm{~min}$. The butanol-pyridine layer was removed and its absorbance at $532 \mathrm{~nm}$ was measured to quantify TBARS.

In all the three above methods, the percent inhibition of scavenging activity was calculated using the following equation (Eq. 1).

Percent inhibition $(\%)=\left(\mathrm{A}_{\text {control }}-\mathrm{A}_{\text {test }}\right) / \mathrm{A}_{\text {control }} \times 100$

where, $\mathrm{A}_{\text {control }}$ is the absorbance of the control and $\mathrm{A}_{\text {test }}$ represents the absorbance of a test substance (TAY/ standard drug).

Tests were performedin triplicate and valueswere obtained as mean \pm SEM of three independent studies. Results were evaluated by comparing the percent inhibition of activity of the TAY with that of standard drugs. Quercetin and gallic acid were used as standard drugs.

\section{Acute oral toxicity study}

Over-night fasted rats were randomly divided into six groups of six animals each. Rats of two different groups were administered with a single dose of 2000 $\mathrm{mg} / \mathrm{kg}$ b.w.of TAY. Normal control was given vehicle alone. The animals were observed individually for first one hour for any gross behavioral changes like drowsiness, restlessness, writhing, convulsions and symptoms of toxicity and mortality, if any, and then periodically for the next $24 \mathrm{~h}$, and then at every $24 \mathrm{~h}$ for any signs of acute toxicity over a period of 14 days. The acute toxicity study was done as per OECD guideline 423 (Oliveira et al., 2008).

\section{Oral Glucose tolerane(OGT) test}

This test was performed in overnight fasted normal ratsaccording to the method reported byJunejo et al. (2014). Animals were divided into four groups of six each. Group I rats (normal control) were treated with vehicle alone. Group II was treated with $T A Y$ at $5 \mathrm{mg}$ / $\mathrm{kg}$ b.w. dose. Group III rats were treated with metformin hydrochloride $(5 \mathrm{mg} / \mathrm{kg}$ b.w.). Carboxymethylcellulose (CMC) solution $(0.5 \% \mathrm{w} / \mathrm{v}$ in normal saline) was used as vehicle. Glucose $2 \mathrm{~g} / \mathrm{kg}$ was fed orally $30 \mathrm{~min}$ after the administration of $T A Y$ ormetformin hydrochloride. Blood was withdrawn from the tail vein at $0,30,60,90$ and $120 \mathrm{~min}$, and glucose levels in blood were estimated by the GOD-POD method(Ye, Shen, Xie, 2002).

\section{Hypoglycemic activity in streptozotocin- induced diabetic rats}

Type II diabetes was induced in overnight fastedanimals by a single intraperitoneal (i.p) injection of streptozotocin (STZ, $55 \mathrm{mg} / \mathrm{kg}$ b.w. in normal saline) (Amira et al., 2016; Shokeen et al., 2008).The animals confirmed as diabetic (after $72 \mathrm{~h}$ of STZ injection) by the elevated plasma glucose levels $(200-300 \mathrm{mg} / \mathrm{dL})$ was used for the experiment.The animals were divided randomly into five groups of six rats in each group.Group I rats served as normal control and were given vehicle $(0.5 \% \mathrm{CMC} w / \mathrm{v}$ in normal saline) alone. Group II rats served as diabetic control and were administered with vehicle alone. Group IIIwas treatedwith $T A Y$ at $5 \mathrm{mg} /$ $\mathrm{kg}$ b.w. Group IV rats were received the standard drug, metformin hydrochloride $(5 \mathrm{mg} / \mathrm{kg}$ b.w.). Treatments were given orally using a canulaonce daily for a period 
of 21 days. Blood was collected from the tail vein each time for the determination of glucose levels on $0,7,14$ and 21 day. Blood glucose levels were measured by the GOD-POD method.

\section{Liver and kidney function tests}

The initial and final body weights were measured. Liver tissues were excised, blotted, weighed and stored at $-70{ }^{\circ} \mathrm{C}$ for assay of glycogen content. Liver glycogen was estimated by the method of Carroll and co-workers (Carroll, Longley, Roe, 1956).Blood was collected by cardiac puncture in dry test tubees containing a mixture of potassium oxalate and sodium fluoride (1:3) and allowed to coagulate in ambient temperature for 30 min. The serum was separated by centrifugation $(2000$ rpm, $10 \mathrm{~min}$ )for estimation of various biochemical parameters. Serum insulin levels were measured by the microplate ELISA method using a commercial kit (SPAN Diagnostics Ltd.). Serum lipid profile was estimated using commercially available kits (SPAN Diagnostics kit). Triglycerides (TG) and Total cholesterol (TC) were estimated by enzymatic methods(Trinder, 1969; Lopeset al., 1977), HDL (How density lipoprotein) cholesterol by phosphotungstate method (Lopes et al., 1977; Allainet al., 1974) and LDL (low density lipoprotein) cholesterol were calculated by Friedewald's formula (Friedewald, Levy, Frederickson, 1972).

Serum was used to estimate glutamate oxaloacetate transaminase (GOT)glutamate pyruvate transaminase (GPT) and alkaline phosphatase (ALP), total protein (TPR) and creatinine (CRTN).SGOT and SGPT were measured by UV kinetic method (Bergmeyer et al., 1976) andALKP was estimated by PNPP method (Klin, 1972; Seligman et al., 1950). TPR was measured by Bradford Macro method (Bradford, 1976), while CRTN was by picrate method (Henry, Canon, Winkelman, 1974).

\section{In vivo antioxidant activity}

On $21^{\text {st }}$ day, all the groups of animals were anaesthetized using diethyl ether, liver was dissected out,washed with normal saline and one part was preservedin $10 \%$ formalin for histopathological studies. The other part of liver was homogenized by ice chilled Tris-HCl buffer and used foractivities/levels of superoxide dismutase(SOD) (Minami, Yoshikawa, 1979), catalase (Xu, Yuan, Lang, 1997), reduced glutathione (GSH) (Beutler, Duron, Kelly, 1983), glutathione peroxidase (GPx) (Rotruck et al., 1973), andmalondialdehydeMDA (Mesbah et al., 2004).The malondialdehyde (MDA) production is a direct indicator of lipid peroxidation (LPO) process that was measured by TBA reaction using an ELISA reader (at $532 \mathrm{~nm}$ ).

\section{Histopathological studies}

At the end of $21^{\text {st }}$ day of treatment, the animals were fasted for $12 \mathrm{~h}$, anaesthetized using diethyl ether and sacrificed by cervical dislocation. Pancreas was instantly dissected out, excised and rinsed in ice-cold saline solution. Tissues were processed as follows. A portion of pancreas tissue was fixed in $10 \%$ formalin fixative solution for 4 days. After fixation, tissues were dehydrated in ethanol (70-95\%), cleared in xylene, and embedded in paraffin was, solid transverse sections of 4-5 $\mu \mathrm{m}$ thickness were obtained by using a rotary microtome. The section were stained with haematoxineosin and histopathological observations were carried out under a light microscope (40x) (Irudayaraj et al., 2012; Kumar, Kumar, Om, 2011).

\section{Statistical analysis}

Statistical analysis was carried out using GraphPad Prism 5.0 (San Diego, USA) (IBM SPSS 19.0 statistical software package, for Windows). Results were calculated as mean \pm SEM of triplicate studies. Data were analyzed by one-way ANOVA followed by Student's $t$-test (Sabu, Smitha, Kuttan, 2002). For biochemical estimations, statistical significance differences were observed with respect to negative control $(p<0.01, p<0.05)$.

\section{RESULTS}

\section{Identification of isolated compound}

The structure of the isolated flavonoid, TAY represented in Figure 1 was elucidated by UV, IR, ${ }^{1} \mathrm{H}$ NMR, ${ }^{13} \mathrm{C}$ NMR and Mass spectroscopic/spectrometric analyses.

TAY (Fraction18-176): $\mathrm{UV} \lambda_{\text {max }}(\mathrm{MeOH}): 272,304$, $340 \mathrm{~nm}\left(\log \varepsilon\right.$ 5.6, 1.1, 0.9); IR $\boldsymbol{v}_{\text {max }}(\mathrm{KBr}): 3465,3372$, $3315,3241,2943,2833,1685,1648,1562,1422,1221$, $1093,876 \mathrm{~cm}^{-1}$; ${ }^{1} \mathrm{H}$ NMR (DMSO-d $)$ : $\boldsymbol{\delta} 8.02(1 \mathrm{H}, \mathrm{d}$, $\left.\mathrm{J}=8.1 \mathrm{~Hz}, \mathrm{H}-2^{\prime}\right), 7.95\left(1 \mathrm{H}, \mathrm{d}, \mathrm{J}=8.4 \mathrm{~Hz}, \mathrm{H}-6^{\prime}\right), 6.94(1 \mathrm{H}$, $\left.\mathrm{d}, \mathrm{J}=8.1 \mathrm{~Hz}, \mathrm{H}-5^{\prime}\right), 6.89\left(1 \mathrm{H}, \mathrm{d}, \mathrm{J}=8.1 \mathrm{~Hz}, \mathrm{H}-3^{\prime}\right), 6.71$ $(1 \mathrm{H}, \mathrm{s}, \mathrm{H}-6), 6.28(1 \mathrm{H}, \mathrm{s}, \mathrm{H}-3), 5.01(1 \mathrm{H}, \mathrm{d}, \mathrm{J}=7.1 \mathrm{~Hz}$, 
$\left.\mathrm{H}-1 / 2^{\prime \prime}\right), 4.68\left(1 \mathrm{H}, \mathrm{m}, \mathrm{H}-5^{\prime /}\right), 4.50\left(1 \mathrm{H}, \mathrm{m}, \mathrm{H}-2^{\prime /}\right), 3.81(1 \mathrm{H}$, m, H-3/), $3.54\left(1 \mathrm{H}, \mathrm{m}, \mathrm{H}-4^{\prime \prime}\right), 3.18(2 \mathrm{H}, \mathrm{d}, \mathrm{J}=4.8 \mathrm{~Hz}$, $\left.\mathrm{H}_{2}-6^{\prime /}\right) ;{ }^{13} \mathrm{C}$ NMR (DMSO- $\left.d_{6}\right): \boldsymbol{\delta} 163.00(\mathrm{C}-2), 102.92(\mathrm{C}-$ 3), 182.55(C-4), 161.59(C-5), 98.61 (C-6), 164.43 (C-7), 146.24(C-8), 156.46 (C-8), 104.51 (C-10), $122.08\left(\mathrm{C}-1^{\prime}\right)$, 128.93(C-2), 116.28 (C-3), 160.86 (C- 4), 114.27 (C-5), 129.41 (C-6), $105.07\left(\mathrm{C}-1^{\prime \prime}\right), 79.15$ (C-2), 73.85 (C-3), 71.05 (C-4), 82.28 (C-5), 61.78 (C-6); $\mathrm{ES}^{+} \mathrm{MSm} / z$ (rel. int.): $448[\mathrm{M}]^{+}\left(\mathrm{C}_{21} \mathrm{H}_{20} \mathrm{O}_{11}\right)(59.0), 431$ (66.3), 330 (1.2), 302 (61.9), 285(9.1).

The isolated flavonoid (TAY) was obtained as pale yellowamorphous powder $(480 \mathrm{mg})$ with a melting range of $250-251{ }^{\circ} \mathrm{C}$. The molecular ion $\left(\mathrm{M}^{+}\right)$peak was obtained at $\mathrm{m} / \mathrm{z} 448.0$ with a relative intensity of 59.0 which concord the molecular formula of the compound as $\mathrm{C}_{21} \mathrm{H}_{20} \mathrm{O}_{11}$. The NMR spectral data also supported the structureof the compound. A signal at $\delta 6.711(1 \mathrm{H}, s)$ showed the characteristic feature of proton at 3-position of the flavone skeleton.Thepresence of chelated hydroxyl group was shown by absorption bands at 337 2and 1648 $\mathrm{cm}^{-1}$ in the IR spectrum with a shoulder at $\lambda$ of $340 \mathrm{~nm}$ in the UV spectrum and by a sharp singlet at $\delta 13.179$ of ${ }^{1} \mathrm{H}$ NMR spectrum. Location of chelated hydroxyl group at
5 -position was shown by a bathochromic shift at $\lambda 430 \mathrm{~nm}$ with $\mathrm{MeOH} / \mathrm{AlCl}_{3}$ in UV. It was found to contain $\beta$ - $D$ glucopyranosyl unit fused through $O$-glycosidic linkage with 7-position of ring $\mathrm{A}$ as evident from the six signals of ${ }^{13} \mathrm{C}$ NMR spectrum at $\delta 105.079(\mathrm{C}-1 \delta), 79.152(\mathrm{C}-2 \delta)$,

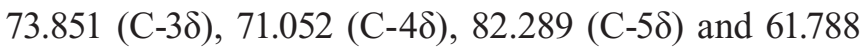
$(\mathrm{C}-6 \delta)$ and $p$-di-substituted phenyl nucleus at 2-position of ring $\mathrm{B}$ as disclosed by its signals of four aromatic protons in ${ }^{1} \mathrm{H}$ NMR constituting $\mathrm{AA}^{\prime} \mathrm{BB}^{\prime}$ systems $(1 \mathrm{H}, d$, $J=8.1 \mathrm{~Hz}, \mathrm{H}-2^{\prime}$ at $\delta 8.036 ; 1 \mathrm{H}, d, J=8.4 \mathrm{~Hz}, \mathrm{H}-6^{\prime} \mathrm{Hz}$ at $\delta$ $7.940 ; 1 \mathrm{H}, d, J=8.1 \mathrm{~Hz}, \mathrm{H}-3^{\prime}$ at $\delta 6.932$ and $1 \mathrm{H}, d, J=8.4$ $\mathrm{Hz}, \mathrm{H}-5^{\prime}$ at $\left.\delta 6.905\right)$. Also, $\beta$-position of anomeric proton of $D$-glucopyranosyl unit at $1 \delta$-position was revealed by $J$ value of $7.1 \mathrm{~Hz}$ of its characteristic signal at $\delta 5.006$ in ${ }^{1} \mathrm{H}$ NMR spectrum. Furthermore, $p$-di-substitutions of hydroxyl groups at 5- and 8-positions of aromatic ring A was confirmed by blue color as positive response diagnosed by Gibb's test (Gibbs, 1974). A thorough spectral interpretation of the spectra of the compound and chemical analysis suggested that the compound is 8-hydroxyapigenin 7-O- $\beta$ - $D$-glucopyranoside. This compound is reported for the first timeas a new compound from the species of $T$. angustifolia.

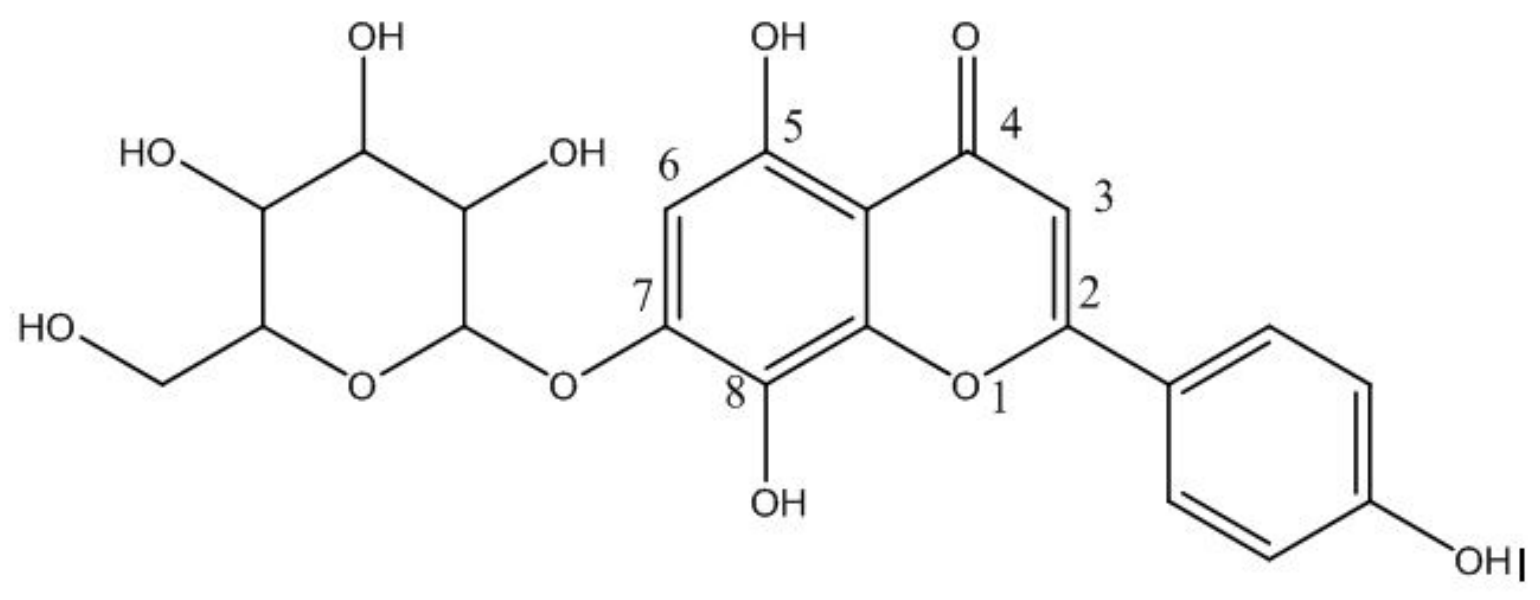

FIGURE 1 - Structure of isolated flavonoid, TAY.

\section{In vitro antioxidant activity}

Superoxide radical scavenging activity

TAY showed superoxide radical scavenging activity in a concentration dependent manner. At the concentration of $50 \mu \mathrm{g} / \mathrm{mL}, T A Y$ exhibited $93.34 \pm 0.43 \%$ of scavenging activity, while, quercetin showed $93.85 \pm$ $0.36 \%$ of scavenging activity at the same concentration. The percent inhibitory activity of TAY was found significant $(p<0.05)$ as compared to the standard drug, quercetin (Figure 2). 


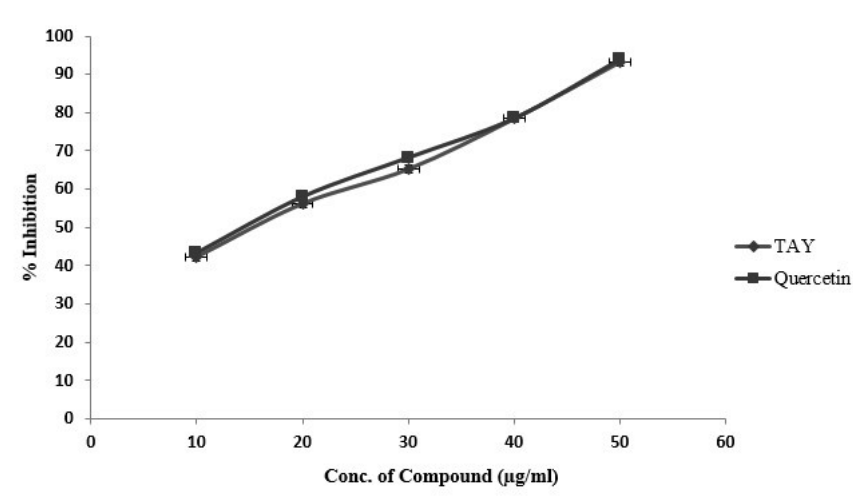

FIGURE 2 - Superoxide radical scavenging activity. Values are mean \pm SEM of three replicate experiments. \%Scavenging activity of $T A Y$ is statistically significant at $p<0.05$, compared to quercetin (standard).

\section{Hydroxyl radical scavenging activity}

The percentinhibition of hydroxyl radicals was $92.34 \pm 0.43 \%$ for $T A Y$ at the concentration of $50 \mu \mathrm{g} / \mathrm{mL}$. The inhibitory activity of TAY was comparable with that of the standard drug, quercetin $(94.85 \pm 0.32 \%)$ at the same concentration. The percent scavenging activity of $T A Y$ was statistically significant $(p<0.05)$ as compared to quercetin (Figure 3).

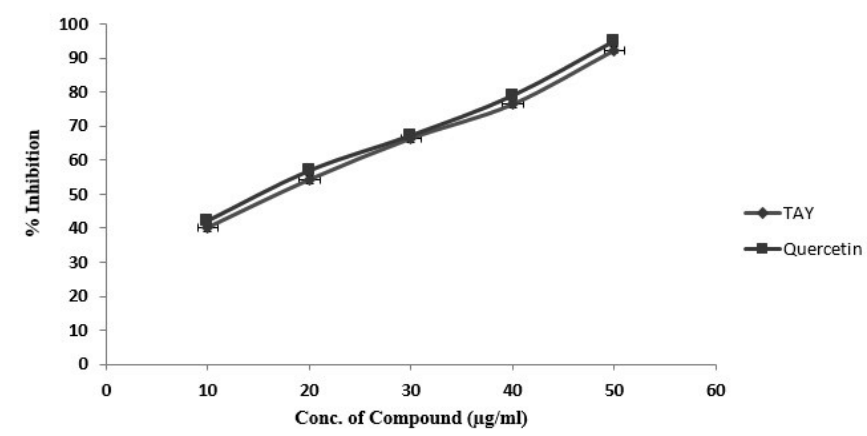

FIGURE 3 - Hydroxyl radical scavenging activity. Values are mean \pm SEM of three replicate experiments. \%Scavenging activity of $T A Y$ is statistically significant at $p<0.05$, compared to quercetin (standard).

\section{Lipid peroxidation scavenging activity}

LP induced by $\mathrm{Fe}^{2+}$ /ascorbate in rat liver homogenate was found to be inhibited by $T A Y$ in a concentration dependant manner and a considerable amount of lipid peroxidation inhibitory effect was observed by $89.19 \pm 0.22 \%$, while, quercetin inhibited by $93.48 \pm 0.35 \%$, at the concentration of $50 \mu \mathrm{g} / \mathrm{mL}$ (Figure 4). Test results were considered statistically significant $(p<0.05)$ as compared to the standard drug, quercetin.

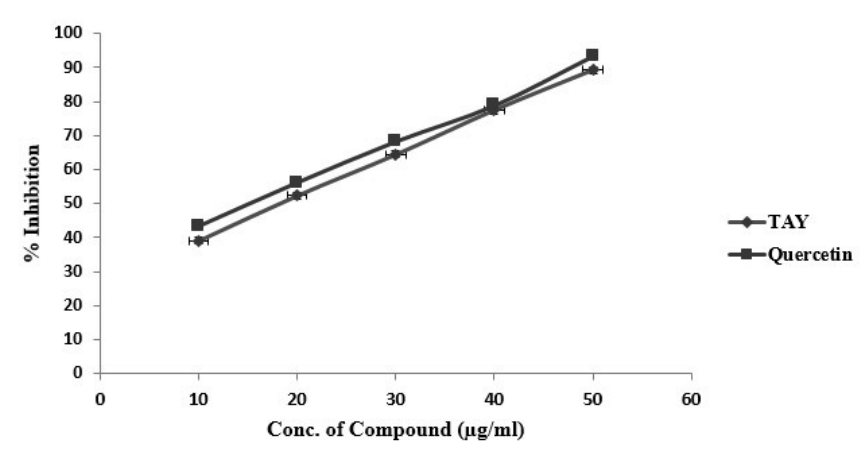

FIGURE 4 - Lipid peroxidation scavenging activity. Values are mean \pm SEM of three replicate experiments. \%Scavenging activity of $T A Y$ is statistically significant at $\mathrm{p}<0.05$, compared to quercetin (standard).

\section{Acute toxicity study}

No sign and symptoms of acute toxicity and mortality up to $2000 \mathrm{mg} / \mathrm{kg}$ body weight dose were observed during the whole experimental period. The body weight and food consumption were normal compared to vehicle treated rats. No significant changes in haematological and biochemical (serum lipids and liver enzymes) parameters were observed.

\section{Effect of TAY on OGT testin normal rats}

In OGT, TAY (5 $\mathrm{mg} / \mathrm{kg})$ showed significant $(p<0.05)$ reduction of blood glucose load compared to normal control group (Figure 5).The activity of $T A Y$ is comparable to the standard drug, metformin $(5 \mathrm{mg} / \mathrm{kg})$.

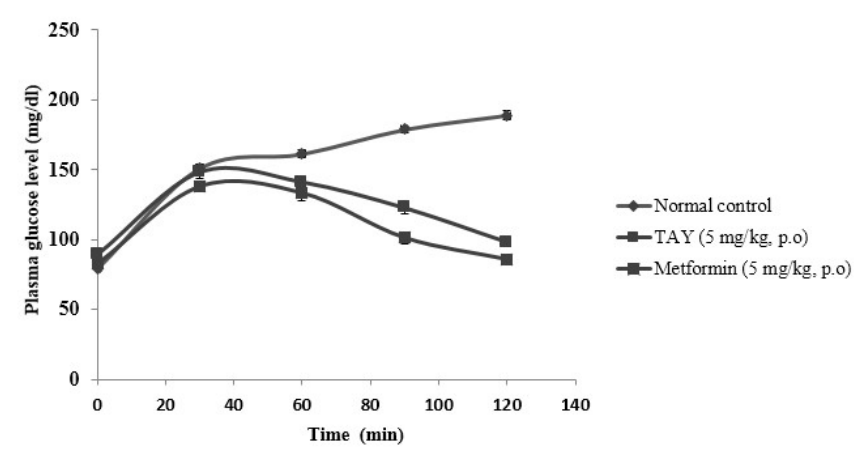

FIGURE 5 - OGT test. Values are mean $\pm \mathrm{SEM}$ of three replicate experiments. Activities of $T A Y$ and metformin are statistically significant at $p<0.05$, compared to normal control. 


\section{Hypoglycemic activity of TAY in streptozotocin-induced diabetic rats}

\section{Effect of TAY on blood glucose levels in diabetic rats}

There was abnormal increase in the levels of blood glucose in STZ-treated diabetic rats. After treatment with TAY $(5 \mathrm{mg} / \mathrm{kg})$ the blood glucose llevels were markedly decreased in diabetic rats. The activity of $T A Y$ is statistically significant $(p<0.05)$ as compared to the normal control rats and is comparable to the standard drug, metformin $(5 \mathrm{mg} / \mathrm{kg})$. Results of the effect of $T A Y$ on blood glucose levels in normal and diabetic rats are summarized in Table I.

TABLE I - Effect of $T A Y$ on blood glucose levels in normal and diabetic rats

\begin{tabular}{|c|c|c|c|c|}
\hline \multirow{2}{*}{ Group } & \multicolumn{4}{|c|}{ Days } \\
\hline & 0 day & $7^{\text {th }}$ day & $14^{\text {th }}$ day & $21^{\text {st }}$ day \\
\hline $\begin{array}{l}\text { Normal } \\
\text { control }\end{array}$ & $97.83 \pm 2.10$ & $\begin{array}{l}101.92 \\
\pm 2.12\end{array}$ & $99.16 \pm 3.23$ & $\begin{array}{l}103.92 \\
\pm 3.19\end{array}$ \\
\hline $\begin{array}{l}\text { Diabetic } \\
\text { control } \\
\text { STZ (55 } \\
\text { mg/kg, i.p) }\end{array}$ & $273.19 \pm 1.92$ & $\begin{array}{c}282.29 \\
\pm 2.18\end{array}$ & $\begin{array}{l}291.37 \\
\pm 3.91\end{array}$ & $\begin{array}{l}332.99 \\
\pm 1.99\end{array}$ \\
\hline $\begin{array}{l}\text { Diabetic } \\
+T A Y \\
(5 \mathrm{mg} / \\
\mathrm{kg}, \mathrm{p.o})\end{array}$ & $\begin{array}{l}269.61 \\
\pm 3.44\end{array}$ & $\begin{array}{l}286.33 \\
\pm 2.89\end{array}$ & $\begin{array}{c}143.19 \pm \\
3.19^{* *}\end{array}$ & $\begin{array}{l}121.30 \\
\pm 2.87\end{array}$ \\
\hline $\begin{array}{l}\text { Diabetic + } \\
\text { Metformin } \\
(5 \mathrm{mg} / \\
\text { kg, p.o) }\end{array}$ & $\begin{array}{c}276.54 \pm \\
3.71^{*}\end{array}$ & $\begin{array}{c}283.75 \pm \\
2.83^{*}\end{array}$ & $\begin{array}{l}118.82 \\
\pm 3.11^{*}\end{array}$ & $\begin{array}{c}99.51 \pm \\
2.43^{*}\end{array}$ \\
\hline
\end{tabular}

Values indicate mean $\pm \operatorname{SEM}(n=6)$

${ }^{*} p<0.05,{ }^{* *} p<0.01$, compared with normal control values.

\section{Effect of TAY on body weight, plasma insulin and liver glycogen in diabetic rats}

Table II depicts the effect of TAY on body weight, levels of plasma insulin and liver glycogen in normal and diabetic rats. In diabetic rats, the body weight, insulin level and glycogen content were significantly reduced. After 21 days of treatment with TAY $(5 \mathrm{mg} /$ $\mathrm{kg}$ ), body weight, insulin level and glycogen content were significantly increasedas compared to diabetic rats. Results are of TAY statistically significant $(p<0.05)$ as compared to the normal rats. The activity of $T A Y$ is comparable to the standard drug, metformin $(5 \mathrm{mg} / \mathrm{kg})$.

TABLE II - Effect of TAY on body weight, plasma insulin and liver glycogen in normal and diabetic rats

\begin{tabular}{|c|c|c|c|c|}
\hline \multirow{2}{*}{ Group } & \multicolumn{2}{|c|}{ Body weight in g } & \multirow{2}{*}{$\begin{array}{l}\text { Plasma } \\
\text { insulin } \\
(\mu \mathrm{U} / \mathrm{mL})\end{array}$} & \multirow{2}{*}{$\begin{array}{c}\text { Liver } \\
\text { glycogen } \\
\text { (mg/g } \\
\text { tissue) }\end{array}$} \\
\hline & 0 day & $21^{\text {st }}$ day & & \\
\hline Normal control & $\begin{array}{l}209.23 \\
\pm 3.30\end{array}$ & $\begin{array}{l}226.21 \\
\pm 3.63\end{array}$ & $\begin{array}{c}16.01 \pm \\
2.21\end{array}$ & $\begin{array}{c}73.54 \pm \\
3.44\end{array}$ \\
\hline
\end{tabular}

Diabetic

$\begin{array}{lcccc}\text { control } & 217.19 \pm & 183.44 & 5.98 \pm & \\ \text { STZ }(55 \mathrm{mg} / & 2.44 & \pm 4.74 & 5.38 & \end{array}$

$\mathrm{kg}$, i.p)

\begin{tabular}{lcccc} 
Diabetic & 212.86 & 219.45 & $14.17 \pm$ & \\
+ TAY & \pm 2.86 & \pm 3.54 & $4.11^{*}$ & $70.63 \pm 5.32$ \\
$(5 \mathrm{mg} / \mathrm{kg}$, p.o $)$ & & & & \\
& & & & \\
& & & & \\
Diabetic + & $218.18 \pm$ & 225.68 & $15.95 \pm$ & $72.97 \pm$ \\
Metformin & $4.80^{*}$ & \pm 3.10 & 5.88 & 5.83 \\
$(5 \mathrm{mg} / \mathrm{kg}$, p.o $)$ & & & & \\
\hline
\end{tabular}

Values indicate mean $\pm \operatorname{SEM}(n=6)$

${ }^{*} p<0.05$, compared with normal control values.

\section{Effect of TAY on lipid profile in diabetic rats}

The effect of $T A Y$ on serum lipid profile of diabetic rats is displayed in Table III. In diabetic rats, the levels 
of triglycerides (TG), total cholesterol (TC), and low density lipoprotein (LDL) were increased and the level of high density lipoprotein (HDL) was decreased. In TAY $(5 \mathrm{mg} / \mathrm{kg})$ treated groups, the TG, TC and LDL levels were significantly reduced and the HDL level was significantly increased as compared to diabetic control rats. The activity of TAY is statistically significant $(p<0.05)$ as compared to the normal rats and is comparable to the standard drug, metformin $(5 \mathrm{mg} / \mathrm{kg})$.

TABLE III - Effect of TAY on lipid profile in normal and diabetic rats

\begin{tabular}{lcccc}
\hline Groups & $\begin{array}{c}\text { TG } \\
(\mathbf{m g} / \mathbf{d L})\end{array}$ & $\begin{array}{c}\text { TC } \\
(\mathbf{m g} / \mathbf{d L})\end{array}$ & $\begin{array}{c}\text { HDL } \\
(\mathbf{m g} / \mathbf{d L})\end{array}$ & $\begin{array}{c}\text { LDL } \\
(\mathbf{m g} / \mathbf{d L})\end{array}$ \\
& & & & \\
& & & & \\
Normal control & $91.20 \pm$ & 157.29 & $42.13 \pm$ & $98.23 \pm$ \\
& 3.99 & \pm 3.11 & 2.34 & 3.24 \\
& & & & \\
Diabetic control & 213.73 & 279.57 & 28.58 & 203.75 \\
STZ (55 mg/ & \pm 2.58 & \pm 1.79 & \pm 3.13 & \pm 2.41 \\
kg, i.p) & & & & \\
& & & & \\
& & & & \\
Diabetic + TAY & 132.62 & 161.50 & $45.89 \pm$ & 122.53 \\
(5 mg/kg, p.o) & $\pm 2.38^{*}$ & $\pm 3.95^{*}$ & 2.49 & \pm 3.17 \\
& & & & \\
Diabetic + & & & & \\
Metformin & 117.96 & 155.49 & $49.85 \pm$ & $89.72 \pm$ \\
(5 mg/kg, p.o) & \pm 1.94 & \pm 2.53 & 2.75 & 2.83 \\
\hline
\end{tabular}

Values indicate mean $\pm \operatorname{SEM}(n=6)$

" $p<0.05$, compared with normal control values.

\section{Effect of TAY on SGOT, SGPT, ALKP, TPR and CRTN in diabetic rats}

There was an abnormal increase in activities of SGOT, SGPT and ALKP in diabetic rats. After treatment with $T A Y(5 \mathrm{mg} / \mathrm{kg})$, the activities of SGOT, SGPT and ALKP activities were significantly reduced in diabetic rats. A significant decrease in serum total protein (TPR) level and a significant increase in creatinine (CRTN) level were also observed in diabetic rats. After treatment with $T A Y$ at $5 \mathrm{mg} / \mathrm{kg}$ doses for 21 days the TPR level was significantly increased and CRTN level was significantly decreased compared to diabetic control rats. The effect of $H A E$ on liver enzymes (SGOT, SGPT, ALKP), TPR and CRTN is significant $(p<0.05)$ as compared to normal control animals and is similar to that of the standard drug, metformin $(5 \mathrm{mg} / \mathrm{kg})$ (Table IV).

TABLE IV - Effect of TAY on SGOT, SGPT, ALKP, TPR and CRTN in normal and diabetic rats

\begin{tabular}{|c|c|c|c|c|c|}
\hline Group & $\begin{array}{l}\text { SGOT } \\
(\mathrm{U} / \mathrm{L})\end{array}$ & $\begin{array}{l}\text { SGPT } \\
(\mathbf{U} / L)\end{array}$ & $\begin{array}{c}\text { ALKP } \\
(\mathbf{U} / \mathbf{L})\end{array}$ & $\begin{array}{c}\text { TPR } \\
(\mathrm{mg} / \mathrm{dL})\end{array}$ & $\begin{array}{c}\text { CRTN } \\
(\mathrm{mg} / \mathrm{dL})\end{array}$ \\
\hline $\begin{array}{l}\text { Normal } \\
\text { control }\end{array}$ & $\begin{array}{c}53.32 \pm \\
2.72\end{array}$ & $\begin{array}{c}44.81 \pm \\
1.53\end{array}$ & $\begin{array}{c}111.32 \pm \\
3.75\end{array}$ & $\begin{array}{c}9.11 \pm \\
0.53\end{array}$ & $\begin{array}{c}0.513 \pm \\
0.031\end{array}$ \\
\hline $\begin{array}{l}\text { Diabetic } \\
\text { control } \\
\text { STZ ( } 55 \mathrm{mg} / \\
\text { kg, i.p) }\end{array}$ & $\begin{array}{c}106.38 \pm \\
1.95\end{array}$ & $\begin{array}{c}90.84 \pm \\
3.17\end{array}$ & $\begin{array}{c}304.33 \pm \\
2.63\end{array}$ & $\begin{array}{c}4.79 \pm \\
0.86\end{array}$ & $\begin{array}{c}0.927 \pm \\
0.028\end{array}$ \\
\hline $\begin{array}{l}\text { Diabetic } \\
+ \text { TAY } \\
(5 \mathrm{mg} / \mathrm{kg}, \mathrm{p} . \mathrm{o})\end{array}$ & $\begin{array}{c}71.29 \pm \\
3.11\end{array}$ & $\begin{array}{c}69.36 \pm \\
3.64^{* *}\end{array}$ & $\begin{array}{c}141.73 \pm \\
3.22\end{array}$ & $\begin{array}{c}8.15 \pm \\
0.57\end{array}$ & $\begin{array}{c}0.617 \pm \\
0.056^{*}\end{array}$ \\
\hline $\begin{array}{l}\text { Diabetic }+ \\
\text { Metformin } \\
(5 \mathrm{mg} / \mathrm{kg}, \mathrm{p} . \mathrm{o})\end{array}$ & $\begin{array}{c}61.43 \pm \\
1.89^{*}\end{array}$ & $\begin{array}{c}51.27 \pm \\
2.76\end{array}$ & $\begin{array}{c}128.82 \pm \\
3.51^{* *}\end{array}$ & $\begin{array}{c}8.92 \pm \\
1.46^{*}\end{array}$ & $\begin{array}{c}0.567 \pm \\
0.032\end{array}$ \\
\hline
\end{tabular}

Values indicate mean $\pm \operatorname{SEM}(n=6)$

${ }^{*} p<0.05,{ }^{* *} p<0.01$, compared with normal control values.

\section{Effect of TAY on liver enzymes and MDA}

Table V displays the activities of SOD, CAT, GSH and GPx in normal and diabetic rats. In STZ-treated diabetic rats, the activities of SOD, CAT, GSH and GPx were abnormally increased. TAY significantly $(\mathrm{p}<0.05)$ reduced the activities of these antioxidant enzymes in diabetic rats as compared to normal rats.Increased levels of MDA, an indicator of LPO, in diabetic rats were significantly reduced after treatment with TAY ( 5 $\mathrm{mg} / \mathrm{kg}$ ) as compared to normal rats. The effect of TAY on liver enzymes and MDAare comparable with that of standard drug metformin $(5 \mathrm{mg} / \mathrm{kg})$. 
TABLE V - Effect of TAY on SOD, CAT, GSH, GPx and MDA in normal and diabetic rats

\begin{tabular}{|c|c|c|c|c|c|}
\hline Treatment & $\begin{array}{c}\text { SOD } \\
\text { (U/mg } \\
\text { protein) }\end{array}$ & $\begin{array}{c}\text { CAT } \\
\text { (U/mg } \\
\text { protein) }\end{array}$ & $\begin{array}{c}\text { GSH } \\
\text { (U/mg } \\
\text { protein) }\end{array}$ & $\begin{array}{c}\text { GPx } \\
\text { (U/mg } \\
\text { protein) }\end{array}$ & $\begin{array}{c}\text { MDA } \\
\text { (LPO) } \\
\text { (U/mg } \\
\text { protein) }\end{array}$ \\
\hline $\begin{array}{l}\text { Normal } \\
\text { control }\end{array}$ & $\begin{array}{c}9.05 \pm \\
0.04\end{array}$ & $\begin{array}{c}74.75 \pm \\
3.45\end{array}$ & $\begin{array}{c}18.11 \pm \\
0.59\end{array}$ & $\begin{array}{c}25.36 \\
\pm 2.57\end{array}$ & $\begin{array}{c}0.64 \pm \\
0.23\end{array}$ \\
\hline $\begin{array}{l}\text { Diabetic } \\
\text { control } \\
\text { STZ }(55 \mathrm{mg} / \\
\text { kg, i.p) }\end{array}$ & $\begin{array}{c}5.68 \pm \\
0.06\end{array}$ & $\begin{array}{c}43.86 \pm \\
2.52\end{array}$ & $\begin{array}{c}7.89 \pm \\
0.34\end{array}$ & $\begin{array}{c}10.85 \\
\pm 0.79\end{array}$ & $\begin{array}{c}0.94 \pm \\
0.05\end{array}$ \\
\hline $\begin{array}{l}\text { Diabetic } \\
+\mathrm{TAY} \\
(5 \mathrm{mg} / \mathrm{kg}, \mathrm{p} . \mathrm{o})\end{array}$ & $\begin{array}{c}8.64 \pm \\
0.07^{*}\end{array}$ & $\begin{array}{c}70.54 \\
\pm 3.23^{*}\end{array}$ & $\begin{array}{c}16.14 \\
\pm 0.48\end{array}$ & $\begin{array}{c}22.94 \pm \\
0.68^{*}\end{array}$ & $\begin{array}{l}0.7 .23 \\
\pm 0.57\end{array}$ \\
\hline $\begin{array}{l}\text { Diabetic }+ \\
\text { Metformin } \\
(5 \mathrm{mg} / \mathrm{kg}, \mathrm{p.o})\end{array}$ & $\begin{array}{c}8.95 \pm \\
0.08\end{array}$ & $\begin{array}{c}73.85 \pm \\
4.39\end{array}$ & $\begin{array}{c}18.02 \pm \\
1.20^{*}\end{array}$ & $\begin{array}{c}24.83 \\
\pm 0.68\end{array}$ & $\begin{array}{c}0.69 \pm \\
0.13\end{array}$ \\
\hline
\end{tabular}

Values indicate mean $\pm \operatorname{SEM}(n=6)$

${ }^{*} p<0.05$, compared with normal control values.

\section{Histopathological observations}

Histopathological studies of pancreas of STZtreated diabetic rats exhibited reduction in the dimensions of islets, damaged $\beta$-cell population and extensive necrotic changes followed by fibrosis and atrophy (B). TAY $(5 \mathrm{mg} / \mathrm{kg})$ and metformin treated rats restored the necrotic and fibrotic changes and also increased the number and increased the size of the islets (C). In normal control group normal acini and normal cellular in the islets of langerhans in the pancreas were observed (A). The changes in pancreas morphology in metrformin treated group (D) are similar to TAY treated rats. The effect of $T A Y$ on pancreatic section in normal and diabetic rats is appended in Figure 6.

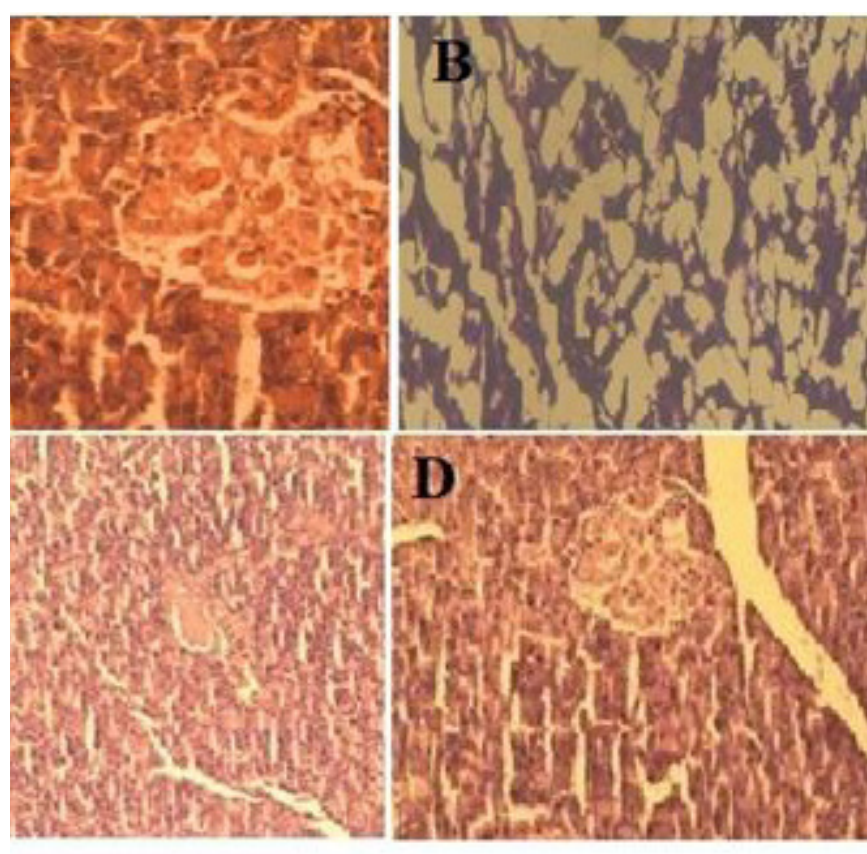

FIGURE 6 - Histology of pancreas of experimental rats after treatment with $T A Y, 500 \mathrm{mg} / \mathrm{kg}$. (A) Normal control, (B) Diabetic control, (C) Diabetic treated with $T A Y(500 \mathrm{mg} / \mathrm{kg})$, (D) Diabetic treated with metformin.

\section{DISCUSSION}

The flavonoid compound, TAY isolated from methanolic extract of $T$. angustifolia leaves exhibited no toxicities or any mortalities up to a dose of $2000 \mathrm{mg} /$ $\mathrm{kg}$ b.w. in experimental rats. Results of acute toxicity study therefore indicates high margin of safety of the isolated flavonoid, TAY. OGT is used to determine the altered carbohydrate metabolism during post glucose administration (Ceriello, 2005). In OGT, TAY showed promising response in lowering increased glucose load of blood. The hypoglycemic effect of TAY was also found significant with marked decrease in fasting blood glucose levels in STZ-induced diabetic rats. Besides glucose lowering effect, TAY significantly increased the level of serum insulin. It is therefore suggested that the hypoglycemic response of TAY might be attributed mainly due to the stimulation of insulin secretion from $\beta$-cells of pancreas. Intraperitoneal administration of STZ destroys partially pancreatic $\beta$-cells and residual $\beta$-cells that secrete insufficient insulin, which ultimately results in diabetes mellitus (Type 2).Increased insulin levels in blood promotes peripheral glucose uptake into the muscle and adipose tissue or reduces the production of glucose by inhibiting hepatic glycogenolysis/gluconeogenesis (Shirwaikar, 
Rajendran, Punitha, 2005; Irudayaraj et al., 2012). The reversal of hyperglycemia is therefore observed due to increased insulin secretion from regenerated $\beta$-cells of pancreas (Punith, Manohara, 2006). Histopathological observations of our study also support the above fact. However, the possible mode(s) of antidiabetic action of TAY might be stimulation of insulin secretion from the $\beta$-cells of pancreas or reduction of insulin resistance by increased utilization of peripheral glucose.

The characteristic loss of body weight in STZinduced diabetic rats was probably due to the increased muscle wasting and protein catabolism (Salahuddin, Jalalpure, 2010). Diabetic rats treated with $T A Y$ showed an improvement in body weight in diabetic rats. This signifies the protective effect of $T A Y$ indegradation of structural proteins. The ability of $T A Y$ to protect body weight loss might be due to improvement in insulin secretion and consequent hypoclycemic response. Glycogen synthesis in the liver and skeletal muscles of rats gets impaired in diabetes (Huang et al., 2000). The liver glycogen content was markedly reduced in diabetic animals, which was in proportion to insulin deficiency. $T A Y$ increased significantly the liver glycogen content of diabetic rats, which could be due to increased insulin secretion. The decrease in hepatic glycogen content in diabetes is due to the lack of insulin which ultimately results in the inactivation of glycogen synthase enzyme (Whitton, Hems, 1975). It is therefore suggested that reactivation of the glycogen synthase enzyme primarily restores the level of liver glycogen.

Elevation of plasma lipid concentration in diabetes is well documented (Chase, Glasgow, 1976). The most common lipid abnormalities in diabetes are hypertriglyceridemia and hypercholesterolemia that are usually linked to obesity, atherosclerosis and other diabetic complications like coronary heart disease (Khan, Abraham, Leelamma, 1995). Hypertriglyceridemia is also associated with metabolic consequences of hypoinsulinemia, insulin resistance and insulin intolerance (Gingsberg, 1994). The increase in serum TG and TC observed in untreated diabetic rats is in agreement with the findings of Annie et al. (2004). Under normal circumstances insulin activates enzyme lipoprotein lipase and hydrolyses triglycerides. Insulin deficiency results in failure to activate the enzymes leading to hypertriglyceridemia (Pushparaj, Tan, Tan, 2000). The significant control of the levels of serum lipids in the $T A Y$ treated diabetic rats might be attributed to improvements in serum insulin levels (Annie et al.,
2004).Significant lowering of LDL cholesterol and raise in HDL cholesterol were observed in treated diabetic rats. (Luc, Fruchart, 1991).

An increase in the activities of SGOT, SGPT and ALP in diabetic rats occurs due to their leakage from liver cytosol into the blood stream which is an indicator of the toxic effect of STZ to liver cells(Kasetti et al., 2010). Treating with $T A Y$ reduced the activity of these enzymes in liver in diabetic rats.It indicates the protective role of flavonoid compound over liver enzymes in diabetic state.Reduction in levels of plasma TPR and CRTN werealso observed in diabetic rats. This is be due to the distinct metabolic renal dysfunction in diabetic state, leading to a negative nitrogen balance, enhanced proteolysis and decreased protein synthesis(Tuvemo et al., 1997; Almdal, Vilstrup, 1988). After treatment $T A Y$, significant improvement in plasma protein levels was observeddiabetic rats. It indicates that the flavonoid compound prevented the progression of renal damage in diabetic rats.

SOD, CAT, GSH and GPx are enzymatic antioxidants that play a vital role in preventing oxidative damage to cells. SOD reduces the superoxide radical into hydrogen peroxide $\left(\mathrm{H}_{2} \mathrm{O}_{2}\right)$. CAT catalyzes the reduction of $\mathrm{H}_{2} \mathrm{O}_{2}$ into oxygen and water molecule and thus protects the tissues against damaging effects of hydroxyl radicals. GSH and GPxarealsoinvolved in the process (Eliza, Daisy, Ignacimuthu, 2010; Halliwell, Gutteridge, 1985). In diabetes mellitus, hyperglycemia causesinactivation of SOD, CAT, GSH and GPx by glycating these proteins which consequently induce cellular oxidative stress through lipid peroxidation (LPO) process. Malonaldehyde (MDA) is one of the end products in LPO process. LPO in the tissue homogenate was determined by measuring the amounts of MDA produced (Rosen et al. 2001).Increased levels of SOD, CAT, GSH and GPxobserved after treatment with TAY indicates the potential of flavonoid compound in the prevention of LPO and associated oxidative stress (OS) in diabetes. Decreased MDA level further supports the role of flavonoid compound in LPO process.

Increasing evidence in clinical studies suggest that OS plays a crucial role in the pathogenesis of both type 1 and type 2 diabetes mellitus. Diabetic complications (atherosclerosis, myocardial infarction, neuropathy, nephropathy) have long been associated with hyperglycemia and cellular OS (Irudayaraj et al., 2012; Sabu, Smitha, Kuttan, 2002; Rosen et al., 2001; John, 1991; Kayama et al., 2015). Plant antioxidants play a vital 
role in the alleviation of oxidative stress in diabetes. STZ produces oxygen radicals, which cause pancreatic injury and thus responsible for the increased blood glucoselevel in animals (Elizabeth, Rao, 1990; Halliwell, Gutteridge, 1985). Moreover, abnormally high levels of free radicals and simultaneous defects innaturalantioxidant defense mechanisms (enzymatic) can lead to the development of insulin resistance. In our study, a marked decrease in the concentration of TBARS and MDA observed in in vitro and in vivo models, respectivelyindicates decline in LPO of tissues and induced OS (Venkateswaran, Pari, 2003; Suresh, Menon, 1993). It signifies the potential role of the isolated flavonoid compoundinlipid peroxidation mechanism aspowerful free radical scavenger or antioxidant. Superoxide directly initiates LPO and plays an important role in the formation of ROS like hydroxyl radicals, which in turn induce oxidative damage in lipids, proteins and DNA. The direct effect of hydroxyl radicals in LPO is several folds more than the superoxide radical. The flavonoid could effectively scavenge these harmful radicals along with the inhibition of LPO by scavenging active oxygen species with the subsequent prevention of the propagation of free radical chain reactions. The reducing property of phenolic flavonoid indicates that it acts as electron donors, which reduce the oxidized intermediates involved in LPO process (Bajpai et al., 2014). Studies (Hagerman et al., 1998; Robak, Gryglewski, 1998) also suggest that high molecular weight plant flavonoids comprising hydroxylated aromatic ring systems serve as potent free radical scavengers due to the formation of reactive phenoxide radical. The phenoxide radical helps suppress LPO/OS through different chemical mechanisms, which includes free radical quenching, electron transfer, radical addition, or radical recombinations (Lamba et al., 2000; Fang, Yang, Wu, 2002). It is now therefore assumed that the antioxidant property of isolated flavonoid compound is primarily responsible for its antidiabetic activity (Ramkumar et al., 2009). The antioxidant action helps to reduces cellular OS and associated hyperglycemic conditions in diabetes (Kusirisin et al., 2009; Bajpai et al., 2014).The compound, 8-hydroxyapigenin 7-O- $\beta-D$ glucopyranoside is a glucoside of 8-hydroxy derivative of apigenin (4',5,7-trihydroxyflavone), a flavones occurring naturally as glycosides in many plant species. Apigenin and its 7-glucoside (Apigetrin), have several health benefits such as anticancer, neuroinflammation and antioxidant properties.Because of having potent hypoglycemic response in STZ-induced diabetic rats, the new flavonoid compound of herbal origin may be used as antidiabetic drug in insulin-resistant diabetic (type 2) patients with potent antioxidant action.

\section{CONCLUSION}

The present study reports anew flavonoidcompound, 8-hydroxyapigenin 7-O- $\beta$ - $D$-glucopyranoside isolated from the methanolic extract of $T$. angustifolia leaves. The flavonoid compound possesses potent antidiabetic (hypoglycemic) activity with antioxidant (radical scavenging activity) potential in STZ-induced diabetic rats. The compound is reported for the first time as a novel flavonoid molecule from the species of T. angustifolia. Studies are in progress in our laboratory for further exploration of biochemical mechanism involved in the antidiabetic action of the isolated flavonoid. However, the isolated flavonoid may play a significant role in ameliorating diabetes mellitus with limited host toxicity or may be used as lead molecule in the development of newer antidiabetic drug candidates for the treatment of insulin resistant diabetes mellitus.

\section{CONFLICT OF INTEREST}

We wish to confirm that there are no known conflicts of interest associated with this publication and there has been no significant financial support for this work that could have influenced its outcome.

\section{ACKNOWLEDGEMENT}

The authors are thankful to Head, Dept. of Pharmaceutical Sciences, Dibrugarh University for his needful help and cooperation to carry out research work. The first author (JAJ) acknowledges the fellowship (SRF) support from the University Grants Commission (Grant number: F1-17.1/MANF-MUS-WES), New Delhi, India.

\section{REFERENCES}

Allain CC, Poon LS, Chan CSG, Richmond W, Paul CF. Enzymatic determination of total serum cholesterol. Clin Chem. 1974;20(4):470-475.

Almdal TP, Vilstrup H. Strict insulin treatment normalizes the organic nitrogen contents and the capacity of urea-N synthesis in experimental diabetes in rats. Diabetologia. 1988;31(2):114-118. 
Amira R, El B, Samy AH, Abeer AA, Yehia AH, Tarek MM. Anti-diabetic activity of Holothuriathomasi saponin.Biomed Pharmacother. 2016;84:1472-1487.

Annie SK, Rajendran C, Kumar D, Bodla R. Antidiabetic activity of aqueous leaf extract of Annona squamosa in streptozotocin-nicotinamide type 2 diabetic rats. J Ethnopharmacol. 2004;91(1):171-175.

Anwal MS, Saka S, Mairiga IA, Sanda KA, Shuaibu A, Ibrahim A. Preliminary phytochemical and elemental analysis of aqueous and fractionated pod extracts of Acacia nilotica (thorn mimosa). Vet Res Forum. 2014;5(2):95-100.

Bajpai VK, Sharma A, Kang SC,Baek KH.Antioxidant, lipid peroxidation inhibition and free radical scavenging efficacy of a diterpenoid compound sugiol isolated from Metasequoiaglyptostroboides. Asian Pac J Trop Dis. 2014;7(1):9-15.

Bergmeyer HU, Bowers GN Jr, Horder M, Moss DW. Provisional recommendations on IFCC methods for the measurement of catalytic concentrations of enzymes. Part 2.IFCC method for aspartate aminotransferase. ClinChimActa. 1976;70(2):F19-29.

Beutler E, Duron O, Kelly BM. Improved method for the determination of blood glutathione. J Lab Clin Med. 1983;61:882-888.

Bradford M.A rapid and sensitive method for the quantitation of microgram quantities of protein utilizing the principle of protein-dye binding. Anal Biochem. 1976;72:248-254.

Carroll NV, Longley RW, Roe JH. The determination of glycogen in liver and muscle by use of anthrone reagent. J Biol Chem. 1956;220(2):583-593.

Ceriello A. Postprandial hyperglycemia and diabetes complications: is it time to treat. Diabetes. 2005;54(1):1-7.

Chakraborty M, Saha S, Mukhapadhyay S. Murrayakoeninol - a new carbazole alkaloid from Murrayakoenigii (Linn) spreng. Nat Prod Commun. 2009;4(3):355-358.

Chase PH, Glasgow AM. Juvenile diabetes mellitus and serum lipids and lipoprotein levels.Am J Dis Child. 1976;130(10):1113-7.

Day C. Traditional plant treatments for diabetes mellitus: pharmaceutical foods. Br J Nutr. 1998;80(1):203-208.

Debasis DE, Chatterjee K, Ali MK, Mandal S, Barik B, Ghosh D. Antidiabetic and antioxidative effects of hydro-methanolic extract of sepals of Salmaliamalabarica in streptozotocininduced diabetic rats.J Appl Biomed. 2010;8(1):23-33.
Eliza J, Daisy P, Ignacimuthu S. Antioxidant activity of costunolide and eremanthin isolated from Costusspeciosus (Koen ex. Retz) Sm. ChemBiol Interact. 2010;188(3): 467-472.

Elizabeth K, Rao MNA. Oxygen radical scavenging activity of curcumin.Int J Pharm. 1990;58(3):237-240.

Fang YZ, Yang S, Wu G. Free radicals, antioxidants, and nutrition.Nutrition. 2002;18(10):872-879.

Friedewald WT, Levy RT, Frederickson DS.Estimation of VLDL- and LDL-cholesterol.Clin Chem. 1972;18(6): 499-502.

Gibbs RD, Chemotaxonomy of flowering plants.Montreal; London:McGill Queen’s University Press; 1974.

Gingsberg HN. Lipoprotein metabolism and its relationship to atheroscelrosis. Med Clin North Am. 1994;78(1):1-20.

Hagerman AE, Riedl KM, Jones GA, Sovik KN, Ritchard NT, Hartzfeld PW. High molecular weight plant polyphenolics (tannins) as biological antioxidants.J Agric Food Chem. 1994;46(5):1887-1892.

Halliwell B, GutteridgeJMC.Free radicals in Biology and Medicine. London:Oxford Clarendon Press; 1985.

Henry RJ, Canon DC, Winkelman JW. Clinical chemistry principles and techniques, New York:Harper and Row; 1974.

Huang X, Vaag A, Hanson M, Weng J, Goop L. Impaired insulin stimulated expression of the glycogen synthase gene in skeletal muscle of type 2 diabetic patients is acquired rather than inherited. J Clin Endocrinol Metab. 2000;85(4):1584-90.

Irudayaraj SS, Christudas S, Duraipandiyan V, Ignacimuthu S. Antidiabetic and antioxidant activities of Toddaliaasiatica (L.) Lam. leaves in streptozotocin-induced diabetic rats.J Ethnopharmacol. 2012;143(2):515-523.

John WB. Role of oxidative stress in development of complications in diabetes.Diabetes. 1991;40(4):405-12.

Junejo JA, Zaman K, Rudrapal M, Mondal P. Antidiabetic assessment of the hydro-alcoholic leaf extracts of the plant Tetrastigmaangustifolia (Roxb.), a traditionally used North-Eastern Indian vegetable. Biomed Pharmacol J. 2014;7(2):635-644.

Kasetti RB, Rajasekhar MD, Kondeti VK, Fatima SS, Kumar EGT, Swapna S, et al.Antihyperglycemic and antihyperlipidemic activities of methanol:water (4:1) fraction isolated from aqueous extract of Syzgium alternifolium seeds in 
streptozotocin-induced diabetic rats. Food ChemToxicol. 2010;48(4):1078-1084.

Kayama Y, Raaz U, Jagger A, Adam M, Schellinger IN, Sakamoto M, et al.Diabetic cardiovascular disease induced by oxidative stress. Int J Mol Sci. 2015;16(10):25234-25263.

Khan BA, Abraham A, Leelamma S. Hypoglycemic action of Murrayakoenigii (curry leaf), Brassica juncea (mustard); mechanism of action.Indian J Biochem Biophys. 1995;32(2):106-108.

Klin Z. Alkaline phosphatase activity is determined by measuring the rate of conversion $p$-nitrophenyl phosphate (pNPP) to p-nitrophenol (pNP). Chemklin Biochem. 1972; 182-192.

Kumar S, Kumar V, Om P. Antidiabetic, hypolipidemic and histopathological analysis of Dilleniaindica (L.) leaves extract on alloxan induced diabetic rats. Asian Pac J Trop Dis. 2011;4(5):347-352.

Kusirisin W, Jaikang C, Chaiyasut C,Narongchai P. Effect of polyphenolic compounds from Solanum torvum on plasma lipid peroxidation, superoxide anion and cytochrome P4502E1 in human liver microsomes. J Med Chem. 2009;5(6):583-588.

Lamba SS, Buch KY, Lewis H, Lamba J. Phytochemicals as potential hypoglycemic agents.Nat Prod Chem. 2000;21(Pt. B):457-495.

Lopes VMF, Stone P, Ellis S, Colwell JA.Cholesterol determination in high-density lipoproteins separated by three different methods.Clin Chem. 1977;23(5):882-884.

Luc G, Fruchart JC. Oxidation of lipoproteins and atherosclerosis.Am J Clin Nutr. 1991;53(1):2065-2095.

Mahdi AA, Chandra A, Singh KR, Shukla S, Mishra LC, Ahmad S. Effect of herbal hypoglycemic agents on oxidative stress and antioxidant status in diabetic rats. Indian J Clin Biochem. 2003;18(2):8-15.

McCord JM, Fridovich I. Superoxide diamutase: an enzymatic function of erythrocuprein. J Biol Chem. 1969;244(22): 6049-6055.

Mesbah L, Soraya B, Narimane S, Jean PF. Protective effect of Flavonoides against the toxicity of vinblastine, cyclophosphamide and paracetamol by inhibition of lipid peroxydation and increase of liver glutathione. Haema. 2004;7:59-67.

Minami M, Yoshikawa H. A simplified assay method of superoxide dismutase activity for clinical use.ClinChimActa. 1979;92(3):337-342.
Ohkawa H, Ohishi N, Yagi K. Assay for lipid peroxides in animal tissues by thiobarbituric acid reaction. Anal Biochem. 1979;95(2):351-358.

Oliveira HC, Santos DMP, GriguloR, Lima LL, Martins DTO, Lima JCS, et al.Antidiabetic activity of Vataireamacrocarpa extract in rats. J Ethnopharmacol. 2008;115(3):515-519.

Patel K, Srinivasan K. Plant foods in the management of diabetes mellitus:vegetables as potential hypoglycemic agents. Nahrung. 1997;41(2):68-74.

Punith R, Manohara S. Antihyperglycemic and antilipidperoxidative effects of Pongamiapinnata (Linn.) Pierre flowers in alloxan induced diabetic rats. J Ethnopharmacol. 2006;105(1-2):39-46.

Pushparaj P, Tan CH, Tan BK. Effects of Averrhoabilimbi leaf extract on blood glucose and lipids in streptozotocin-diabetic rats.J Ethnopharmacol. 2006;72(1-2):69-76.

Ramkumar KM, Manjula C, Sankar L, Suriyanarayanan $\mathrm{S}$, Rajaguru P. Potential in vitro antioxidant and protective effects of Gymnemamontanum $\mathrm{H}$. on alloxan-induced oxidative damage in pancreatic $\beta$-cells, HIT-T15. Food Chem Toxicol. 2009;47(9):2246-2256.

Robak J, Gryglewski RJ. Flavonoids are scavengers of superoxide anions. Biochem Pharmacol. 1998;37(5):837-841.

Rosen P, Nawroth PP, King G, Moller W, Tritschler HJ, Packer $\mathrm{L}$. The role of oxidative stress in the onset and progression of diabetes and its complications: a summary of a Congress Series sponsored by UNESCO-MCBN, the American Diabetes Association, and the German Diabetes Society. Diabetes Metab Res Rev. 2000;17(3):189-212.

Rotruck JT, Pope AL, Ganther HE, Swason AB. Selenium: biochemical role as a component of glutathione peroxidase. Science. 1973;179(4073):588-590.

Sabu MC, Smitha K, Kuttan R. Anti-diabetic activity of green tea polyphenols and their role in reducing oxidative stress in experimental diabetes. J Ethnopharmacol. 2002;83(1-2): 109-116.

Salahuddin M,Jalalpure SS. Antidiabetic activity of aqueous fruit extract of Cucumistrigonus Roxb. instreptozotocininduced diabetic rats. J Ethnopharmacol. 2010;127(2): 565-567.

Seligman AM, Chauncey HH, Nachlas MM, Manheimer LM, Ravin HA. The colorimetric determination of phosphatases in human serum. J Biol Chem. 1950;190(1):7-15.

Shirwaikar A, Rajendran K, Punitha ISR. Antidiabetic activity of alcoholic stem extract of Coscinium fenestratum 
instreptozotocin-nicotinamide induced type 2 diabetic rats. J Ethnopharmacol. 2005;97(2):369-374.

Shokeen P, Anand P, Murali YK, Tandon V. Antidiabetic activity of $50 \%$ ethanolicextract of Ricinuscommunisand its purified fractions. Food Chem Toxicol. 2008;46(11): 3458-3466.

Souza MF, Rao VSN, Silveira ER. Inhibition of lipid peroxidation by ternatin, a tetramethoxyflavone from Egletesviscosa L. Phytomed. 1997;4(1):25-29.

Suresh JS, Menon VP.Effect of diabetes on levels of lipid peroxides and glycolipids in rat brain. Metabolism.1993;42(11):1435-1439.

Trinder P. Quantitative determination of glucose using the GOP-PAP method. Clin Biochem 1969;6:24-27.

Tuvemo T, Ewald U, Kobboh M, Proos LA.Serum magnesium and protein concentrations during the first five years of insulin dependent diabetes in children.Acta Paediatr. 1997;418:7-10.
Venkateswaran S, Pari L. Effect of Coccinia indica leaves onantioxidant status in streptozotocin-induced diabetic rats.J Ethnopharmacol. 2003;84(2-3):163-168.

Whitton PD, Hems DA. Glycogen synthesis in perfused liver of streptozotocin diabetic rats.Biochem J. 1975;150(2): 153-65.

Xu JB, Yuan XF, Lang PZ.Determination of catalase activity and catalase inhibition by ultraviolet spectrophtometry. Environ Chem. 1997;16:73-76.

Ye F, Shen Z, Xie M. Alpha-glucosidase inhibition from a Chinese medicinal herb (Ramulusmori) in normal and diabetic rats and mice.Phytomed. 2002;9(2):161-166.

WHO Global Report on Diabetes.World Health Organization, Geneva, Switzerland; 2016.

Received for publication on $30^{\text {th }}$ October 2018 Accepted for publication on $02^{\text {nd }}$ January 2019 